\title{
Seeing Anew: the role of student leadership in professional learning
}

\section{ACCEPTED FOR LfPL SPECIAL ISSUE}

\author{
Stephanie Hill \\ University of Cambridge, Cambridge, UK \& Passmores Co-operative Learning Community, \\ Harlow, UK \\ s.hill@passmoresacademy.com \\ @stephhill58
}

\begin{abstract}
Growing interest in the role of student agency within schools, as well as the need for effective professional learning, emphasises the importance of further investigation into initiatives aiming to develop meaningful and sustainable student involvement in school improvement approaches. This article explores the role of student leadership in professional learning approaches that aim to improve learning through collaborative reflection on teaching practice. It provides a review of literature that investigates student involvement in professional learning, specifically through the development of student voice and the inclusion of students as co-researchers in school improvement initiatives. Following this, the article draws on the findings from a case study that examined the role of a Student Learning Community (SLC) in professional learning and presents an overview of current practice where students are involved in a research approach to professional learning called a Best Practice review. The insights drawn from the case study and practice example, both situated in a secondary school in England, offer considerations for educators wishing to explore and/or introduce student leadership approaches to professional learning, as well as recommendations for further study into the role of students as agents in school improvement initiatives.
\end{abstract}

Keywords - student agency, student leadership, learning communities, student researchers, professional learning

\section{Acknowledgements}

The author would like to thank Dr Elaine Wilson, Faculty of Education, University of Cambridge, whose expertise, contributions and guidance were integral to the research process. Extended gratitude goes to the practitioners and students from the case study school for participating in this research. The author is grateful to Dr Sue Swaffield, Faculty of Education, University of Cambridge for her valuable comments on earlier drafts and would 
also like to acknowledge the editors of this journal and anonymous reviewers for their suggestions.

\section{Biographical Note}

Stephanie Hill is Associate Assistant Principal (Teaching \& Learning) at Passmores Cooperative Learning Community. Her masters and doctoral research at the Faculty of Education, University of Cambridge focuses on student involvement in professional learning and school improvement initiatives.

\section{Introduction}

There is little doubt that the current state of education within the UK is dominated by accountability structures and external measures of performativity that often result in schools, and teachers within schools, focusing disproportionately on the quantifiable outcomes of their students. A propensity increasingly evident in several Western countries, schools are judged on their ability to produce human capital, measured against a standardised criteria of student achievement (Pearce \& Wood, 2019). This not only has a detrimental effect on the wellbeing and learning of students, but also on the professional learning and personal development of teachers (Hargreaves, 2010; Ball, 2003). This article argues that traditional accountability and improvement mechanisms often lead to a problem-focused approach to professional learning, focusing predominantly upon what is missing and needs fixing. In response to this, it explores an alternative approach that places student leadership at its centre with the purpose of improving learning through transformative dialogue between teachers and students about what works best in teaching practice.

In her analysis of case study methodology, Helen Simons (1996) explores the paradox between the study of the unique and the need to find a universal understanding that can be applied in other contexts. She argues that in order to discover new knowledge about the world we must interact with the tension between the two. When applied to learning, this tension can be seen between what is commonly known (the universal) and a willingness to explore different ways of seeing the world (the unique). In professional learning in schools, this tension can be seen between the universal expectations, measurements and paradigms of quality education, and the unique stories of how learning occurs within schools, and within individuals. One might suggest that it is the preoccupation with the universal in education, through standardised testing and fixed performativity measures, that has too often led to poor quality learning and a deterioration in the relationships between teachers and students. Alternatively, by seeking to understand and value the unique contexts of schools and classrooms, as well as the different ways that young people interact with our world, we can more successfully move towards education that is fulfilling, inspiring and transformative. 
As such, it will be argued here that the involvement of students in conversations about learning enables educators to interact with the unique: with diverse ways of seeing, knowing and practicing that leads to learning grounded in the lived experiences of those within schools. Furthermore, purposeful student leadership approaches to professional learning can encourage educators to take risks in their teaching practice, challenge fixed notions of education, and creatively and collaboratively discover new ways of seeing. Factors which are fundamental to transformational professional learning.

To live with ambiguity, to challenge certainty, to creatively encounter, is to arrive, eventually, at 'seeing' anew. (Simons, 1996, p.238)

This article will provide a review of literature that investigates student leadership in professional learning, starting with an overview of the theoretical development of student agency and following this, the involvement of students as researchers or co-researchers in school improvement initiatives. It will also draw on the findings from a case study (Hill, 2019) that examined the role of a Student Learning Community (SLC) in professional learning in a secondary school in the UK, and provide a reflection of a research approach to professional learning that emerged as a result. Finally, the article will consider the implications and limitations of these approaches in order to draw recommendations for educators who wish to develop student agency initiatives in other school settings.

\section{Background Literature: the role of student agency in a changing context}

\section{Challenging the certainty of our educational context}

There is a growing body of literature suggesting that policy changes and school improvement mechanisms in recent decades have resulted in a fragmented school landscape within the UK, and across many Western countries (Pearce \& Wood, 2019; Bahou, 2012; Hargreaves, 2010; Rudduck \& Fielding, 2006; Ball, 2003). Undoubtedly, accountability measures that evaluate the effectiveness of schools using an external framework of performativity are timely, cost-effective and quantifiable. However, Fielding (2001a) argued at the turn of this century that this results in the professional worth of teachers and schools being almost entirely judged using a narrow and pervasive accountability system that is more concerned with readily measurable means than the wellbeing and development of individual teachers, and the learning of students. Driven by a preoccupation with what is universal across schools, this has too often led schools to privilege a common, reduced curriculum, standardised testing and quality criteria designed at a government level. This inevitably undervalues what is needed for a particular school and the community that this school serves. As MacBeath, Dempster, Frost, Johnson and Swaffield (2018) have discussed, there are examples across the 
world of school leaders and teachers "ensnared in the vertical accountability web" (p. 12) and policy that is "by design discriminating and by impact dehumanising" (p. 162). Hence, schools are challenged to consider how they respond to the destructive impact this has on the learning experiences of our young people.

In many cases, this is encouraging professionals and academics to explore other mechanisms of school improvement that recognise individual contexts and multiple ways of learning. These include alternative accountability measures that are generated within schools, by schools (Fullan, 2013; Hargreaves \& Fullan, 2012), networking communities across schools (Hargreaves, 2010), and the development of learning communities that are created and developed by teachers (Hargreaves \& O'Connor, 2018; Andrews \& Lewis, 2007; Bolam et al., 2005). It has also led to a renewed focus on distributed leadership (Margolis \& Dorling, 2012; Harris, 2008; Harris \& Muijs, 2005) and the role that leadership plays in generating quality learning. Leadership is viewed here as an activity or practice that, beyond positions of power, requires individuals to work together to understand and develop purpose, context and agency within an organisation: a "conjoint agency which focuses on interactions among individuals and groups of 'actors'" (MacBeath et al., 2018, p. 93). Leadership as activity assumes a fluidity and constant movement between the macro and micro contexts of schools (Dempster, 2009). In particular, the need to negotiate the tension between these contexts: the macro (universal) level of policy and standardised expectations, and the micro (unique) experiences within each school. Seen in this way, not only is leadership a practice experienced in some form by every member of a school organisation, but it also requires individuals to continually engage in learning so that they can successfully interact with the universal and the unique.

This is aligned with the concept of a learning organisation, which asserts that for an organisation to truly thrive, learners from every corner of the organisation should be mobilised to interact through structured and sustained learning processes (Mooloi, 2010; Kontoghiorghes, Awbrey \& Feurig, 2005; Ortenblad, 2002). As Senge et al. (2012) assert, "learning is at once deeply personal and inherently social; it connects us not just to knowledge of the abstract, but to each other" (p. 4). Thus, professional learning - the ongoing learning of each individual teacher within a professional context - is fundamental in creating the learning culture required for a school organisation to flourish. MacBeath et al.'s (2018) leadership for learning principles and practices provide a fitting explanation of professional learning that is based upon developing professional integrity, collaborative research and practice, and divergent thinking about learning and teaching. This acknowledges that each teacher "will have her own learning practice - just as she has her own teaching practice" (p. 17). Consequently, professional learning that is prescriptive and based upon universal expectations and criteria is unlikely to prove effective. Instead, we must look to the unique and diverse lived experiences of those within each school, in order to provide professional learning that is relevant, thoughtful and truly has an impact upon the community that each 
school serves. In light of this, student leadership can play a pivotal role in the learning of teachers. For in finding purposeful ways of sharing diverse lived experiences of learning, student leaders can support teachers in building a deeper understanding of their own practice.

\section{Acknowledging the controversy around student voice}

Increasingly, literature suggests that students must sit at the center of school improvement initiatives (Czerniawski \& Kidd, 2011; Cook-Sather, 2010; Atweh \& Bland, 2007; Lundy, 2007; Jackson, 2003). As McIntyre, Pedder and Rudduck (2005) have argued, "it cannot tenably be claimed that schooling is primarily intended to benefit pupils if pupils' own views about what is beneficial to them are not actively sought and attended to" (p. 150). However, as Groundwater-Smith and Mockler (2015) comment in their paper on the shift of student voice from data source to involvement as joint constructors of knowledge, "engaging with student voice is both risky and challenging business in this troubling age" (p. 1). Pearce and Wood (2019) also warn that the construct of student voice is complex, contested and varies across contexts. Accordingly, this article takes a poststructural theoretical approach to student voice, which sees voices as emerging only in connection to other voices, such that students' voices are not completely autonomous but dependent upon context and the interaction with others (Pearce \& Wood, 2019, p. 115).

The use of student voice as a constructivist mechanism for school improvement (Fielding, 2012; Roberts \& Nash, 2009; Mitra, 2004) has come under scrutiny because of the instrumental addition of student voice to school improvement plans: as an urgent response to inspections that are underpinned by fear and control (Atweh \& Bland, 2007; Rudduck \& Fielding, 2006) or as a valorised mechanism that is little more than a passing fad (Bahou, 2012). In many cases, opportunities for students to speak have been restricted to peripheral school matters such as features of the school yard, the food in the canteen or changes to the school uniforms (MacBeath \& Mortimore, 2001); very little was concerned with matters at the heart of schooling - the learning of each student. Fielding commented that "teaching and learning remain largely forbidden areas of enquiry" (2001a, p.101) and if addressed, they are framed and interpreted by teachers, for teachers. Or even more damaging than this, by school leaders for the benefit of school inspections and external expectations.

\section{Finding the space for creative encounters}

It is for this reason that enabling authentic opportunities for student involvement in professional learning is even more important. As student voice can offer the social transformation needed in schools (Pearce $\&$ Wood, 2019) by reminding us of existential realities of human experience (Fielding, 2012) in a context where the universal across schools is currently considered more important than the unique experiences in schools. As one student describes: "I would like to tell the whole world about how important it is to let children have fun in school ... [so it does not become] a dungeon trapped in its own dullness, 
a prison blowing away fun and school trips, sucking out laughter and playfulness' (Alison, Y6)" (Fielding, 2001a, p.102).

In order to enable meaningful student involvement, educators must create spaces for students to speak for themselves, not through the voices of adults (Fielding, 2012; Rudduck \& Fielding, 2006). Mitra's (2004) study discussed the dangers of an adult interpretation of student voice as they invariably translated the students' words into 'adult speak', which in most cases, did not have the same meaning. Consequently, teachers and researchers often misunderstand the perceptions of our young people, and disregard what they are truly trying to say. To counter this, schools need to provide opportunities for students to be heard with their own voice, to enable them to be integral to the interpretation process, and for school leaders and teachers to constantly question whose interests are served when students speak (Cook-Sather, 2010).

Moreover, there is a need for educators to develop the ability to truly listen to students before we can learn with them (Bahou, 2012; Bragg, 2007). Although teachers are beginning to listen in ways that have been fleeting in the past, particularly through formative assessment mechanisms, it still remains that "those in power too often do not listen, even if they hear what is said" (Fielding, 2001a, p.103). In her programmes, Teaching and Learning Together, and later the Students as Learners and Teachers (SaLT) programme, Cook-Sather (2006) focused upon the value of high school students as teachers, as well as learners, through opportunities for pre-service teachers to develop their pedagogical approaches by learning from the student perspective. She concluded that the key message in the study was "learning to speak by listening"; as one pre-service teacher articulates, "telling someone that students should be heard is an effective argument in itself, but actually listening to students and hearing what they have to say and integrating their input into your own life is astronomically more effective'"' (p.351). In light of this, literature concerning student agency is underpinned by an understanding of the importance of teachers and students having a physical and metaphorical space in which they can listen to each other, then learn together and find a shared moral purpose within their school (Fullan, 2013). As Roberts and Nash (2009) comment, "legislation which compels schools simply to listen to students rather than empower them to act continues to ignore young people's potential" (p.175). As such, Fielding (2010) suggests that it is the work of schools to create professional learning spaces where teachers and students can be reflective about their lived experiences in school, to make meaning out of their collective learning, and to agree to the shared responsibility of transforming their school.

There is evidence that the involvement of the diverse perspectives of students in professional learning approaches leads to the improvement of pedagogy. Rudduck and McIntyre's (2007) seminal research, carried out in the Teaching and Learning Research Programme, found that conversations with students about what was happening in classrooms not only led to improvement in teaching practice but also enabled students to see themselves as active 
contributors in this improvement. Similarly, in her research, Mullis (2011) explored professional learning models where students were learning partners, departmental advisors and researchers, working alongside teachers in improving learning. Notably, as Morgan (2011) cautioned in her study on consulting pupils within the classroom, the success of these approaches is contingent upon key contextual conditions that support and encourage this practice. Her work points to the importance of acknowledging external mandates and outside agencies in any student involvement initiatives. For ultimately, external support is needed if student leadership is to become a sustainable part of professional learning approaches. Yet this support could be slow to arrive and minimal when it does. So schools are left to develop initiatives at a grassroots level, which is a distinct possibility considering all that students have to offer their schools. As Thomson and Gunter (2007) have commented, there is growing recognition from schools, and the systems within which they exist, that students "have expertise as well as experience, are capable of responsible action, and can usefully contribute to decisions that affect their everyday lives" (p. 327). Accordingly, schools in the current education context would benefit from models of practice that empower creative encounters between teachers and students. Practice that encourages students to engage in leadership as an activity where they interact with unique views of learning within their context, they form a shared moral purpose with teachers, and they become agents for meaningful improvement in teaching practice.

\section{Exploring the ambiguity of learning through student-led research}

Without doubt, the notion of learning is contentious and ambiguous. As MacBeath (2009) notes, "we still have much to learn about learning and much to learn about how learning can be led, in and out of school" but "...to focus solely on the children's learning is to miss the point" (p. 7). In fact, to focus solely on student learning is likely to be most detrimental to the students themselves. For by valuing their own professional learning, educators engage in conversations about the inherent ambiguity of learning, and the need to constantly engage in the practice of adapting ways of learning within different contexts. What effective learning looks like in one classroom will be very different to the next classroom, and beyond this, it will be different across schools. By embracing the ambiguity of learning, educators also acknowledge that standardised, universal notions of what learning should look like in every school are insufficient, and that the practice of teaching also requires a continual, reflective engagement with how learning thrives in each unique context.

Scholarship in this field has suggested that involving students in school-based research encourages educators to consider the ambiguity of learning and question the status quo: "students as researchers gain new ways of knowing and producing knowledge that challenge the common sense views of reality with which most individuals have grown so comfortable" (Kincheloe \& Steinberg, 1998, p. 2). This is evident in Thomson and Gunter's (2007) students- 
as-researchers project in a North England secondary school, where a group of students engaged in extensive research around bullying in their school by interviewing fellow students using photo elicitation. Their work showed that by placing students at the centre of research about important areas of the school, educators not only gain insight into the perspectives of the student researchers but also the diverse points of view of the students they engage in the research. The students-as-researchers approach to student leadership differs from others in that students are asked to negotiate working with data and adopting a research persona. As Thomson and Gunter note, they are "like teachers, simultaneously both insiders and outsiders" (2007, p. 331), interacting with knowledge and skills, but also analysing how knowledge and skills are mobilised in classrooms.

Similarly, in the Students as Researchers (SAR) programme investigated by Bahou (2012) students "inform[ed] their teachers about how they perceived their learning conditions and what might help them to learn better, how they preferred to learn, and what kinds of relationships and teacher qualities affected them" (p.242). Roberts and Nash (2009) focused more specifically on the issues of student empowerment in their analysis of a $S A R$ programme, which found that the programme led to an enhanced relationship between teachers and students, a more acute awareness of the responsibilities as well as rights of students in contributing to school improvement, and a more developed understanding of what it meant to be agents of change in an organisation. Despite this, however, they note that some students still considered themselves more as advisors than as actors. Nonetheless, it can be argued that this approach enables students to develop a shared understanding of the values and principles of the school and engage in a process of negotiation concerning their own conditions for learning.

Overall, literature concerning student involvement in professional learning suggests that where student agency exists, students feel that they have a role in bringing about change in their school. Students become drivers, rather than passengers, in school improvement. Hence, there is a clear link between student agency and the notion of leadership as the continual practice of navigating the tension between universal and unique views of learning in order to find a shared purpose and contribute to improvement within their school context.

\section{Seeing Anew: two cases of student leadership in professional learning}

Below are two examples of approaches to professional learning that are driven by student leaders who have become agents in improving learning at Passmores Academy, a secondary academy of approximately 1,200 students in Essex, England. The school is located in an area of social deprivation and the proportion of disadvantaged pupils and those with special 
educational needs (SEN) is above the national average with approximately one-third of students receiving Free School Meals and/or SEN provision. I hold a professional role on the school's teaching and learning team and played a central role in developing the SLC, hence potential researcher bias is acknowledged in both the empirical study and practice approach described below. The inclusion of perspectives from teacher and student participants serves to limit this bias and provide insight into their experiences in this area. Their responses are included here using pseudonyms with a first name for students and title and surname for teachers.

\section{Student Learning Community}

In recognition of the valuable role that students can play in professional learning, the student learning community (SLC) emerged as a way of bringing students together in a community that encouraged collective learning and supported student agency. From its introduction in 2014, the SLC created "conditions for students to engage in dialogue with each other concerning their learning, and to invite teachers into this space to do the same" (Hill, 2019, p. 149). Ultimately, it aimed to position both teachers and students as co-learners and enquirers who felt a "strong sense of co-ownership and of co-production" (Beech, Macintosh \& MacLean, 2010, p. 1362).

However, when the SLC was introduced, little research existed concerning students collaborating and communicating with teachers in learning communities. Consequently, the model was informed by practice and literature examining professional learning communities as focused and planned spaces for teachers to collaborate, adapt and reflect on their teaching practice (Hargreaves \& Fullan, 2012; Andrews \& Lewis, 2007). As well as scholarship concerning professional dialogue, which explains it as a mechanism for knowledge coproduction that is intergenerational, transformative, inclusive, and creates a foundation for further constructive activities and professional learning (Pearce \& Wood, 2019; Beltramo, 2018; Hennessy, Mercer \& Warwick, 2011). Of particular use was Beech, Macintosh and MacLean's (2010) definition of dialogic encounters as the "engagement between two or more people that goes beyond the trivial, which changes some meanings or processes and/or creates some new knowledge" (p. 1342). The influences of power dynamics discussed by Fielding (2012) and Cook-Sather (2010), together with Swaffield's (2008) consideration of the importance of acknowledging and negotiating power differentials so that all parties feel respected and valued within dialogue, provided useful recommendations when designing the dialogue sessions that occurred within the learning community.

In practice, the SLC engaged in four areas of collective learning with teachers: (1) collecting and discussing examples of great learning in lessons; (2) participating in lesson visits and engaging in dialogue with the teacher afterwards about the learning; (3) facilitating short 15- 
20 minute lessons to show how different strategies and approaches could enhance the learning of their peers; (4) engaging in professional learning sessions alongside staff where they discussed issues surrounding pedagogy and shared their findings around examples of great learning.

The SLC was the focus of a multi-phase case study (Hill, 2019) that used a purposive sample of teachers $(n=10)$ and student members of the SLC $(n=14)$. The study employed a mixed methods approach (Tashakkori and Teddlie, 2010) that allowed quantitative (quan) and qualitative (qual) data from items in the questionnaire to be used as visual stimulus for the semi-structured interview (QUAL) phase (see Figure 1). The research was developed as a revelatory case study as it presented "an opportunity to observe and analyze a phenomenon previously inaccessible to scientific investigation" (Yin, 1994, p, 40). This was fitting for smallscale research and it is based on representativeness of the concept of student agency rather than representativeness of school sites (Mitra, 2004). Notably, this limited the external validity of the findings but it is particularly useful in overcoming traditional paradigms of evaluation within the field of education that seek to "eliminate difference, rather than highlight them" (Simons, 1996, p.227).

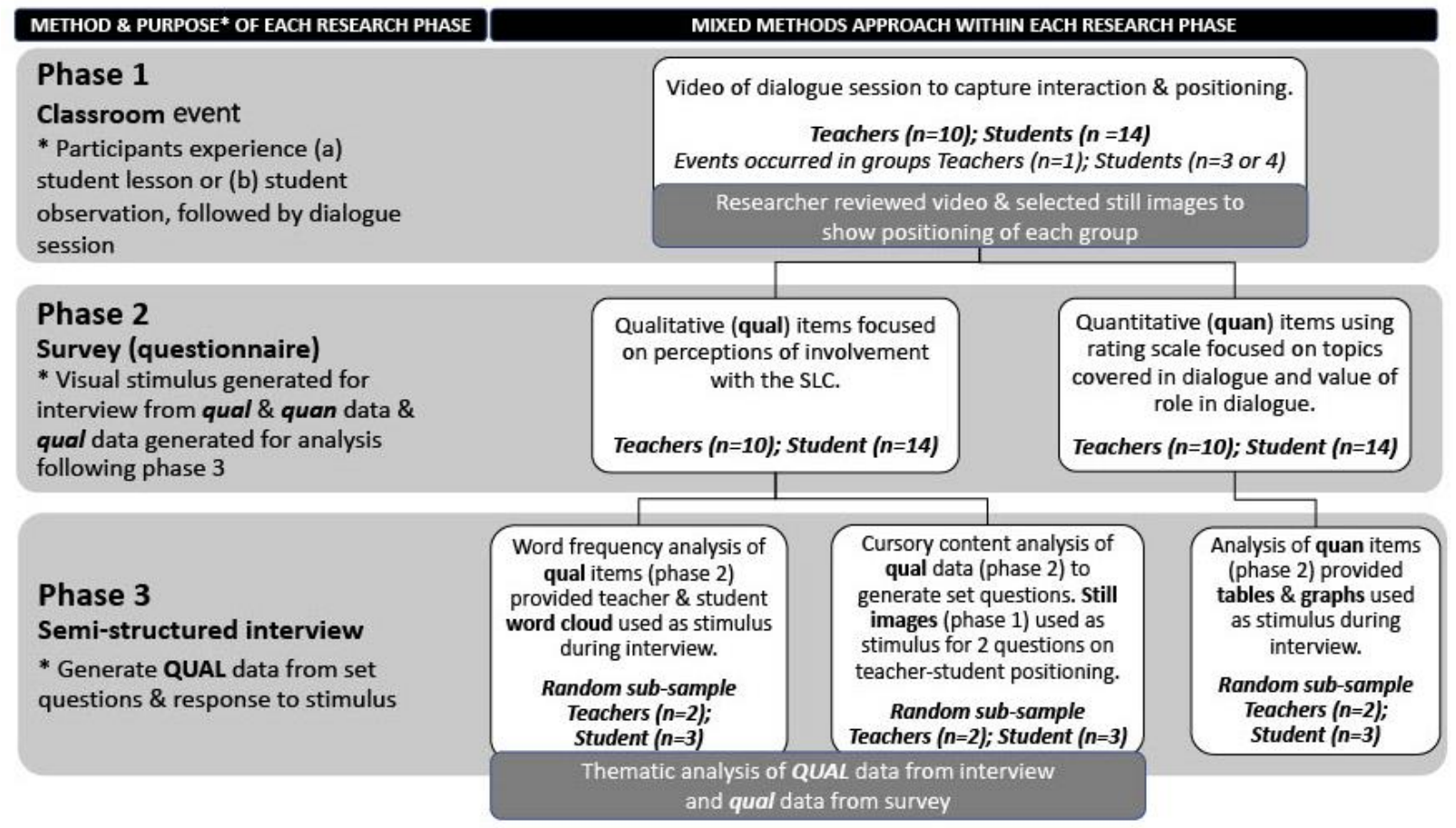

Figure 1 - Phases of research

Overall, the study found that by including students as a key component in its professional learning approach, the school was able to develop as a learning organisation, as stakeholders engaged in learning with and from each other as a means of improving the organisation and promoting individual mastery (Senge, 2012; Giles \& Hargreaves, 2006). In particular, the SLC enabled teachers to consider their assumptions concerning learning and their perspectives on their teaching practice. Most importantly, "it emerged from the research that students do 
not need to be experts in content to contribute to school improvement, instead they enable teachers to also see themselves as learners, a fundamental condition to improving teaching practice" (Hill, 2019, p. 156). And in seeing themselves as learners, teachers engaged purposefully with the unique learning experiences of both students and teachers, and professional learning was focused upon what worked best within the school, rather than based upon universal and generalised expectations of practice. A summary of the key findings can be found in Table 1, which shows the themes drawn from the original data analysis with an outline of student and teacher perspectives within each theme. Notably, these are not generalisations of all student and teacher responses but a summary of the range of perceptions offered in the both the survey and interview. The case study also revealed several limitations of the SLC; these are outlined in the table along with recommendations for introducing a similar student involvement model in other schools. From these findings, two key themes emerged when exploring the role of student involvement in professional learning.

\begin{tabular}{|c|c|c|c|c|}
\hline Themes & $\begin{array}{l}\text { Student (SLC) Involvement } \\
\text { Student perspectives }\end{array}$ & $\begin{array}{l}\text { Professional Learning } \\
\text { Teacher perspectives }\end{array}$ & $\begin{array}{l}\text { Limitations of the SLC Model } \\
\text { Considerations for Practice* }\end{array}$ & $\begin{array}{l}\text { Emerging } \\
\text { Themes }\end{array}$ \\
\hline $\begin{array}{l}\text { Honest } \\
\text { and authentic } \\
\text { awareness of what } \\
\text { works }\end{array}$ & $\begin{array}{l}\text { Students... } \\
\text { - discussed actionable ideas of what } \\
\text { worked } \\
\text { - demonstrated pedagogical ideas } \\
\text { through student lessons }\end{array}$ & $\begin{array}{l}\text { Teachers... } \\
\text { - discussed experiences of } \\
\text { teaching/learning with students } \\
\text { that revealed assumptions about } \\
\text { their practice and led to reflection }\end{array}$ & $\begin{array}{l}\text { most students found it more } \\
\text { difficult to explain why certain } \\
\text { pedagogy worked for them } \\
\text { *metacognition workshops would } \\
\text { be beneficial to develop this }\end{array}$ & 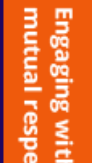 \\
\hline $\begin{array}{l}\text { The role of mutual } \\
\text { respect in developing } \\
\text { meaningful learning }\end{array}$ & $\begin{array}{l}\text { - felt valued as their considerations } \\
\text { about learning were given full } \\
\text { attention } \\
\text { gained insight into role of teacher } \\
\text { and developed more profound } \\
\text { respect }\end{array}$ & $\begin{array}{l}\text { felt that making meaning during } \\
\text { dialogic encounters enabled } \\
\text { students and teachers to } \\
\text { overcome language barriers and } \\
\text { learn together }\end{array}$ & $\begin{array}{l}\text { - students were aware that some } \\
\text { teachers were not interested in } \\
\text { considering their perspectives } \\
\text { - *teacher involvement with the SLC } \\
\text { needs to be voluntary to ensure } \\
\text { engagement with students }\end{array}$ & 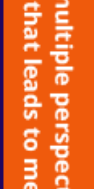 \\
\hline $\begin{array}{l}\text { Teamwork softening } \\
\text { the power hierarchy } \\
\text { in schools }\end{array}$ & $\begin{array}{l}\text { - recognised the unfamiliarity in } \\
\text { visiting lessons in a different role } \\
\text { - felt they had to use pre-defined } \\
\text { adult language to be listened to } \\
\text { - highlighted some teachers } \\
\text { unwillingness to listen to students }\end{array}$ & $\begin{array}{l}\text { - acknowledged that having a space } \\
\text { for team learning (teachers/ } \\
\text { students) disrupted traditional } \\
\text { power hierarchy in schools } \\
\text { with a fixed mindset were more } \\
\text { challenged by dialogue with } \\
\text { students }\end{array}$ & $\begin{array}{l}\text { - physical positioning in some } \\
\text { dialogue sessions showed } \\
\text { students were still seen as } \\
\text { receivers \& responders, not agents } \\
\text { * *space and place should be } \\
\text { carefully considered }\end{array}$ & 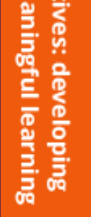 \\
\hline $\begin{array}{l}\text { The shared } \\
\text { ownership of school } \\
\text { transformation }\end{array}$ & $\begin{array}{l}\text { - expressed a sense of responsibility } \\
\text { for improving their school } \\
\text { - showed awareness when their } \\
\text { ideas were implemented } \\
\text { - showed an interest in learning } \\
\text { how to contribute further }\end{array}$ & $\begin{array}{l}\text { - suggested that SLC model made } \\
\text { them accountable to the } \\
\text { expectations of teaching/learning } \\
\text { saw the SLC as encouraging } \\
\text { collaborative growth that was } \\
\text { invited not enforced }\end{array}$ & $\begin{array}{l}\text { - teachers warned of manipulating } \\
\text { student agency to meet needs of } \\
\text { school leaders/ external agencies } \\
\text { * *students should drive the nature of } \\
\text { their involvement in school } \\
\text { improvement }\end{array}$ & 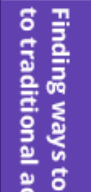 \\
\hline $\begin{array}{l}\text { The role of student } \\
\text { agency in supporting } \\
\text { marginal voices and } \\
\text { different perspectives }\end{array}$ & $\begin{array}{l}\text { - showed awareness that their voice } \\
\text { represented others - often using } \\
\text { "we" and "us" } \\
\text { enabled perspectives on learning } \\
\text { not usually accessed through } \\
\text { teacher-led professional learning }\end{array}$ & $\begin{array}{l}\text { - negotiated disagreement and } \\
\text { differences with students in } \\
\text { dialogue sessions } \\
\text { - engaged in the co-creation of new } \\
\text { knowledge and practice }\end{array}$ & $\begin{array}{l}\text { - marginal voices were } \\
\text { underrepresented here } \\
\text { *spaces \& opportunities created to } \\
\text { invite marginal voices into dialogue } \\
\text { to foster inclusive pedagogy }\end{array}$ & 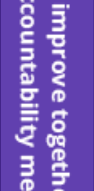 \\
\hline $\begin{array}{l}\text { Transgressing } \\
\text { uncertain ground to } \\
\text { build self-confidence }\end{array}$ & $\begin{array}{l}\text { - overcame inhibitions and } \\
\text { insecurities around sharing } \\
\text { perspectives/ ideas } \\
\text { - developed self-confidence that } \\
\text { stretched beyond the study events } \\
\text { into their own learning practice }\end{array}$ & $\begin{array}{l}\text { teachers experienced increased } \\
\text { confidence \& willingness to make } \\
\text { changes in their teaching/learning } \\
\text { practice }\end{array}$ & $\begin{array}{l}\text { - initial uncertainty and } \\
\text { nervousness existed } \\
\text { could stem from lack of structure } \\
\text { during dialogue } \\
\text { * training \& structure is crucial for } \\
\text { dialogue to be valuable }\end{array}$ & 岁总 \\
\hline
\end{tabular}

Table 1 - Summary of findings emerging from case study 


\section{Engaging with multiple perspectives: developing mutual respect that leads to meaningful learning}

It was found that engaging with students following the classroom event enabled teachers to see different perspectives on the lived experiences of learning in their school. The ideas were found to be honest and pragmatic and accompanied by mature reasoning (Hill, 2019). As Mrs. Kay reflected, "they avoided saying things like 'sit with friends'...they were honest about what happens, they were aware of what happens", and as Sarah recounts, during the dialogue "[we] discussed the importance of interesting starters to engage students in learning before the lessons begin as well as the importance of plenaries, so that students recognise what they have learnt". Students were aware that what they offered may be unique, but were still confident in sharing: "...we were able to show and share our teaching ideas with staff even if they were different" (Daniel). This supports MacBeath et al.'s (2019) assertion that "dialogue, especially among people from different contexts, opens up new perspectives, often generating challenges to established patterns of thought" (p. 45). Hence, it was the act of asking teachers to consider their mental models (Argyris, 1991) by discussing other perspectives on learning that had a significant impact on changing their teaching practice.

Interestingly, it was found that these dialogic encounters created a collegial transparency that also enabled students to see another perspective on their education: "it's odd seeing it from a teacher's point of view...have more respect for teachers now" (Beth). In addition, student participants acknowledged a developed understanding of the challenges experienced by teachers. As Cassie explained, "students don't understand how much time teachers spend, it has opened my eyes a bit more on the planning. You spend an hour on a plan for each lesson, it is quite difficult to do". Moreover, Daniel commented that, "seeing teaching styles and how teachers do things...get more insight into it. When there are misbehaving students, you can see how it affects others, you don't really see how much the lesson gets disrupted usually". This finding is supported by Fielding's (2012) ten-point plan, Schools for Democracy, which describes the development of 'radical roles' that ask teachers and students to interact in different roles, in order to learn through different perspectives (p.61). These unique perceptions created a sense of empathy that stimulated mutual respect and encouraged students to critically reflect upon themselves as learners. It also fostered a shared understanding that enabled a metaphorical space where teachers and students could learn and develop together.

This has also been addressed in studies conducted by Cook-Sather (2010), which found that when brought into conversations about teaching and learning, students developed more understanding of how teachers work and participated more positively in their own learning journey. She notes how the sense of responsibility in one high school student had changed: "it made me think about how to be a better student 'cause it makes you think that a teacher is up there and they worked hard to come up with this lesson plan..." (Cook-Sather, 2002, 
p.10). Furthermore, Pedder and Mclntyre's (2006) study into teacher response to pupil consultation found that pupils contributed ideas that were of benefit to teachers and when their suggestions were taken seriously, a social capital condition was created that led to the sense of mutual respect, trust, confidence and solidarity between teachers and students.

The study also found that "mutual learning comes as much from disagreement as from consensus" (Hill, 2019). This is evident in Samantha's observation: "(the teachers) listened... some ideas they didn't agree with, there were things that they questioned, but that was good as it helped us as well". For Robert, these differing viewpoints were opportunities: "I didn't see it as disagreements, more like taking other people's ideas and discussing them". It is these disagreements, or unique perspectives, that make space for the creative encounters that Simons (1996) saw as fundamental to discovering knowledge that would lead to meaningful learning. When reflecting on the dialogue session, one teacher participant noted that everyone "offered a different dimension to the conversation where differing ideas highlighted an alternative approach to a topic" (Mr. Grange). He saw the differences as enabling progress and new learning; as Fielding (2004) asserted in his work, "in those differences lie the possibilities of creativity and renewal" (p.307). Notably though, students did not always have the metacognitive skills to justify differing ideas or to explain why a particular strategy worked well for their learning. This is a consideration also shared by Hunter and O'Brien (2018) who suggest that it is difficult for students to imagine and evaluate something different from what they have experienced, and to reflect upon their own thinking and assumptions about a particular phenomenon without specific learning in this area. Consequently, teachers may struggle to change their teaching practice when they do not understand the purpose for this change.

\section{Finding ways to improve together: an alternative to traditional accountability measures}

It has been argued here that traditional accountability measures alone are damaging and ultimately ineffective as they fail to recognise the unique lived experiences of students in different contexts. Research into the SLC found that student leadership in professional learning could offer an alternative by encouraging teachers to discuss students' experiences of learning in their school and consequently, reflect upon and adapt their own practice. Participants in the study wanted to see the model (students visiting lessons and delivering short lessons) continue as a professional learning process: "I would like to have the students involved at the planning stage, then we could plan together; I deliver; we evaluate the strategy and the delivery of the strategy and 'replan' as a result" (Mr Watson). Building on this, a student participant, Beth, suggested there could be "another observation later to see whether the plans have been put in place". Additionally, Miss Spark expressed how valuable it was to be observed in this manner as it enabled more authentic insights into the teaching and learning within the classroom: 
observers...for them, they see a lesson just like normal. It is more of a true reflection as I wasn't as nervous.... whenever I'm observed I get very anxious...(but with student observers) it was massively different, a lot less intimidating...they realise that you're not a performing monkey...they understand.

It was found that student involvement in professional learning differed from traditional accountability measures, such as observations from external or internal observers, where teachers were left isolated after a feedback process that was largely unconnected to the lived experiences of their students. Instead, dialogue with students about their learning was relevant; there was authentic and sustained insight into everyday classroom practice, and the process was seen as "a joint means through which a lesson could be discussed and improvement could occur collaboratively" (Hill, 2019, p. 155). As is explained in Warwick et al. (2011), dialogic pedagogy "requires teachers and learners to actively comment and build on each other's ideas, posing questions and constructing shared interpretations and new knowledge" (pp.304-305). It not only offers feedback on learning experiences, but the means through which joint progress can be made. Markedly, one teacher in the study did warn of the danger of students becoming "like Ofsted inspectors potentially delivering the deus ex machina on a professional's work" if their involvement was driven by senior leaders and teachers rather than designed and evaluated by the students themselves. This is an important consideration for any schools involved in student agency initiatives of this nature. In this case, it was clear from the student participants that they felt ownership over this process of mutual learning, and were hopeful that their involvement in professional learning could lead to improvement across their school. As Cassie commented, "this has been valuable for improving my learning as I am able to analyse lessons better and help to improve the teaching within the school". Similarly, Fielding (2001a) found in the Students as Researchers Project that dialogue between teachers and students supported "the transformative notion of education at the heart of which lies the commitment to teaching and learning as a genuinely shared responsibility" (p.137).

\section{Student Leadership in Best Practice approaches}

The outcomes of the case study have enabled the SLC to contribute more purposefully to an evidence-based approach to professional learning. Since 2018, the school has adapted its approach to teaching and learning development across departments by introducing an annual Best Practice review.

The Best Practice approach aims to move away from the 'external measures' used in traditional reviews, where senior leadership visit departments across the school and review the quality of teaching and learning practice, focusing in the most part on ineffective practice. Instead, the purpose of this approach was to bring teachers and students together 
in a process where they discussed best practice within and across departments as a way of broadening ideas, encouraging a curious approach to teacher development, and repositioning collegial learning as central to meaningful improvement across the school. It draws upon literature concerning Appreciative Inquiry approaches (Waters \& White, 2015; Calabrese, 2006; Ryan, Soven, Smither, Sullivan \& Vanbuskirk, 1999), where there is a collective effort to "search for the best in people, their organizations, and [their] world. It involves the discovery of what gives 'life' to a living system when it is most effective, alive, and constructively capable in economic, ecological, and human terms" (Cooperrider et al., 2003 , p. 3). Notably, this ethnographic method has faced criticism due to its perceived 'fuzzy' approach to development and potential to create unrealistic perceptions of the experiences in an organisation (Grant \& Humphries, 2006; Fitzgerald, Murrell \& Newman, 2001). Yet this method of collecting data within schools aims to counter the disproportionate amount of time spent identifying and addressing acute issues and deficits in organisations. Instead, it focuses on enhancing what is working well in the hope that this practice, and approach to learning, will continue to improve and spread.

The description below draws upon artefacts created during the process, as well as written responses from teachers gathered via email as feedback following the review. A more comprehensive survey of the process with teachers and students is planned and so what follows is a description of the process rather than an analysis of its impact.

\section{Phases of the Best Practice Review}

The approach was discussed with teaching staff at the beginning of the year and, based upon their feedback, an overview of each phase of the review was constructed. In the first phase, the SLC collected examples of what works well for them in their learning across all their subjects. They discussed these within the group, focusing on why their examples led to purposeful learning. In Phase 2 the SLC presented their examples (using images and annotated descriptions) at a collaborative session with a small group of staff. They created an electronic presentation of their findings that was later shared with all staff. Alongside this, Heads of Department collated and presented their own examples of best practice within their subject. These examples fit within one of the whole school development areas (such as student growth through feedback). In the third phase, each member of the SLC engaged in a series of Shared Learning Experiences (SLES) - lesson visits - across one day following the timetable of a chosen student. As one teacher, Miss Simon, commented, this "allowed the [student leaders] to gain greater insight into the different learning experiences of a variety of students across the school, [to see what was happening]...with a fresh set of eyes". During each SLE, the student leaders took notes based around a series of inquiry questions that they had collectively designed during a discussion about several key development areas for the school: growth through feedback; stretch and challenge; memory and retention; and learning environment. Following the SLEs, the SLC discussed their experiences and created a Best Practice report for each department. They also engaged in generative dialogue with any 
teachers who wanted to discuss the student leaders' experiences in their lesson. As Miss Simon added, this is "an effective, yet non-judgemental approach as it supports teacher development and student progress...[and is also]...a particularly successful way of building relationships with students, allowing them to feel that they had a voice when it came to their own learning".

Although not all teachers chose to engage in this voluntary stage of the review, it was found to have a significant impact upon those who did. As Ms Packer reflected,

\begin{abstract}
Before I worked with the Student Pedagogy Team I would have deemed it totally inappropriate to have feedback from students. However, once you work with young people and realise that they are not making judgments about teachers, you realise it will inevitably improve teaching practice to work with them... [they work] as collaborators they discuss what helps them to learn and give you ideas for how they've seen it work.
\end{abstract}

\title{
Passmores Research Community
}

This approach aligned with another research into practice model that has been running for two years: the Passmores Research Community. This community, made up of both a teacher and student group, conducted action research on areas of interest using a structure adapted from the Spirals of Inquiry approach to research in schools (Timperley, Kaser \& Halbert, 2014). It aimed to encourage staff and students to engage in research with the purpose of generating evidence-based ways of improving learning, as well as expanding ideas and perspectives. The research reports from the Passmores Research Community, as well as the annotated best practice examples and SLE reports from the Best Practice Review, were compiled in the annual Passmores Research and Practice Journal (Passmores Academy, 2019), which is accessible below.

\section{Recommendations and considerations for practice}

In drawing upon examples from a small-scale revelatory case study, this article is limited in its ability to generalise beyond one school setting. The use of self-report based upon the perceptions of students and teachers is also limiting and there is a need for further investigation into the processes and mechanisms that drive these professional learning approaches. Nonetheless, the empirical study into the SLC, as well as ongoing reflection concerning current practice in student leadership, offers some insight into the implementation of a student learning community as a continual, integrated approach to professional learning within schools. Below are some key factors that are worthy of consideration when implementing a student leadership approach to professional learning.

\section{Enabling a space for meaningful dialogue}


A key consideration in student agency approaches is how educators create a space where students and teachers can feel confident and comfortable in their conversations about learning, and ultimately teaching practice. It was found in the study that generative dialogue requires a set of skills that enables more than the surface-level discussion. In some cases, students were clear on their learning preferences at a superficial level, but teachers and students had not reached a stage in dialogue where they were problem solving and evaluating their own thinking and assumptions. The recent introduction in the case study school of metacognition workshops with the SLC has enabled students to begin to develop these skills. Moreover, Swaffield and Dempster (2009) also note that scaffolded, disciplined dialogue is needed to support and fuel conversations focused on learning and to ensure that dialogue between teachers and students is underpinned by understanding, trust and purpose.

Thus, structured and ongoing training is needed to ensure that students' contributions are meaningful and foster a sense of confidence for both teachers and students. As Miss Clark remarked in the study, "if the students had more observation training, it would give me even more confidence in their judgments, they could come observe me every week". As Rudduck and Fielding (2006) contend, young people must "learn how to enter into a dialogue with others in order to transform practice" (p.223). Similarly, Rushton, Charters and Reiss (2019) found that students engaged in research with teachers through a Student as Partners (SaP) approach wanted more opportunities to develop skills in asking good questions. Alongside this, as per Mr Knott's suggestion, teachers would also benefit from training in dialogic practices: it is "a matter of having the right kind of conversation with students, as the student is someone who can genuinely focus on quality teaching and learning". Notably, students participated in a short course that included two workshops based on coaching principles, as well as three sessions where they watched videos of lessons and discussed where they identified meaningful learning and how it was happening. However, it was clear that students needed a more extensive course where they were able to develop and reflect upon their own practice with the support of teachers. An evidence-informed approach such as Pearce and Wood's (2019) reflective dialogic tool for student involvement would be useful here.

\section{Acknowledging and addressing power differentials}

Notably, it is crucial that we distinguish between skills for engaging in dialogue and observation, and training that threatens the authenticity of student insights. As some teachers indicated in the study, there are inherent dangers of student involvement becoming a tool solely intended for accountability and organisational improvement, where input from students becomes inauthentic and results in teachers feeling disciplined and judged. This runs the risk of undermining the mutual respect and trust that has been built up through the dialogic culture as "teachers would become threatened where they could be invigorated, defensive where they could be open and exploratory..." (Fielding, 2001a, p.108). Thus, if 
student leadership approaches to professional learning are to become a valid alternative - or addition - to traditional accountability measures and standardised training, they must find a balance between providing adequate training and support for students, whilst nurturing the intuition and authenticity of student input. So that it seeks "to promote children's involvement in ways that recognise the competence of children and emphasise the importance of the perspectives of those living the experience" (Dockett \& Perry, 2007, p.48). As Thomson and Gunter (2007) assert, for teachers to see learning in a new light, there must be a shift in the generational power relations in any school setting. However, we must be mindful in creating models of student agency that "honour but do not romanticise or unnecessarily privilege the points of view of students" (p. 340). Being aware of the physical space where dialogue takes place could be useful here as the positioning of students and teachers can address the power differential that can inhibit the development of mutual respect.

\section{Remaining inclusive and avoiding tokenism}

Criticism of student leadership approaches to professional learning derives largely from confusion concerning the role of the child in school (Thompson, 2009; Rudduck \& Fielding, 2006), as well as scepticism about whether students can contribute to teaching practice with any level of expertise and criticality (Black, 2011). As facilitators of these initiatives, it is important to acknowledge this but also to emphasise to teachers that students do not need to be experts in content to discuss their lived experiences of learning and thus contribute to the development of teaching practice. Difference "were clear differences among pupils in the articulacy with which they expressed their views" (Mclntyre et al., 2005, p. 153).

Previous research has found that there is evidence of initiatives such as these "leading to tokenism where the initial novelty of student involvement and dialogic encounters bolsters unrealistic expectations and manipulation from school leaders" (Hill, 2019, p. 158), which ultimately damages the mutual respect and trust between teachers and students, and the desire for students to contribute to professional learning (Fielding, 2012). Thus, it is crucial that schools establish approaches and models that are well supported, achievable and can be sustained over time. And most importantly, we need to ensure marginalised students (who are traditionally less likely to involve themselves in these initiatives) are mobilised to participate, or at the very least, included in some way. As Miss Simon reflected, "the [SLC] are a small selection of students from the school community and may not take into consideration other examples or strategies of the best practice".

\section{Conclusion}


Too often professional learning approaches fail to provide meaningful learning opportunities because of a disproportionate focus on universal expectations, standards, curriculum and criteria, and a tendency to ignore the unique perspectives and ways of learning within the community that each school serves. It has been established that the notion of learning requires individuals and groups to interact with new knowledge, so that learners are able to see the world in new ways. As such, for educators to engage in meaningful learning in their professional roles, they must go beyond merely fulfilling a set of standardised criteria. Instead, they must engage in spaces where they are discovering new practice, acknowledging and discussing multiple perspectives on learning, and finding ways to integrate this into their own identity as an educator. These spaces emerge out of the activity of leadership within a school, which I have explained here as the purposeful process of navigating the tension between the universal and the unique, which, as Simons (1996) contends, is essential in seeing the world authentically and expanding knowledge. Student leadership is pivotal in exploring this tension, for it is the involvement of students in dialogue and research about the learning within a school that enables teachers to address their own assumptions and challenge the effectiveness of their own practice.

Notably, in this article I do not dismiss the need for universal knowledge and standardised expectations in schools. As policy and educators have a responsibility to ensure that all young people have access to a certain standard of schooling. However, I argue that by privileging the universal over the unique, policies and national accountability measures in the UK (and in many countries across the world) are failing to acknowledge, develop and celebrate the unique learning and learners present in different school contexts. As Garvin, Edmondson and Gino (2008) explain, organisations and governments have historically "overemphasized the forest and paid little attention to the trees" (p. 2).

By drawing on literature from across the world and the evolving practice within one school context, I propose that it is possible to develop a professional learning approach where learning sits at the heart of the lived experiences of both students and teachers, and teachers learn from students, as much as students learn from teachers. An approach that is drawn from growing evidence that students can be powerful agents and catalysts for change in school improvement and that there are valuable links between agency and the role of student leadership in professional learning approaches (Pearce \& Wood, 2019; Czerniawski \& Kidd, 2011; Cook-Sather, 2010; McIntyre, Pedder \& Rudduck, 2005).

In an era where the traditional role of teacher as the purveyor of knowledge and facilitator of skills is rapidly being transformed by effective and responsive digital tools, we must ask ourselves what we can bring to this profession. I believe that what sets us apart as educators is our ability to acknowledge, understand and embody the unique perspectives and contexts of our young people, so that their learning experiences at school are safe, inspiring and enduringly compassionate. It is what makes teachers exceptional and reinforces our need to 
continue to navigate the tension between the universal and the unique, so that we never allow universal standards and expectations to drown out the unique experiences and contexts of our students, and our schools.

While faith is certain, knowledge is provisional. Instruction tends to hide this under a veneer of certainty, but an element of uncertainty is necessary in all education of quality. (Stenhouse, 1983, pp. 211-212)

\section{References}

Andrews, D. \& Lewis, M., 2007. Transforming practice from within: the power of the professional learning community. In L. Stoll \& K. Seashore Louis, eds. Professional Learning Communities: Divergence, Depth and Dilemmas. Maidenhead: Open University Press.

Argyris, C., 1991. Teaching smart people how to learn. Harvard Business Review, 4(2), 4-15. Bahou, L., 2012. Cultivating student agency and teachers as learners in one Lebanese school. Educational Action Research, 20(2), 233-250.

Ball, S.J., 2003. The teacher's soul and the terrors of performativity. Journal of Education Policy, 18(2), 215-228.

Beech, N., MacIntosh, R., \& MacLean, D., 2010. Dialogues between Academics and Practitioners: The Role of Generative Dialogic Encounters. Organization Studies, 31 (9\&10), 1341-1367.

Beltramo, J.L., 2018. Developing Mutual Accountability between Teachers and Students through Participation in Cogenerative Dialogues. International Journal of Student Voice, 3 (1). https://ijsv.psu.edu/?article=developing-mutual-accountability-between-teachers-andstudents-through-participation-in-cogenerative-dialogues

Black, R., 2011. Student participation and disadvantage: limitations in policy and practice. Journal of Youth Studies, 14(4), 463-474.

Bolam, R., McMahon, A., Stoll, L., Thomas, S., Wallace, M., Greenwood, A., Hawkey, K., Ingram, M., Atkinson, A., Smith, M., 2005. Creating and Sustaining Effective Professional Learning Communities. Universities of Bristol, Bath and London, Institute of Education.

Bragg, S., 2007. "But I listen to children anyway!" - teacher perspectives on pupil 
voice. Educational Action Research, 15(4), pp.505-518.

Calabrese, R.L., 2006. Building social capital through the use of an appreciative inquiry theoretical perspective in a school and university partnership, International Journal of Educational Management, 20(3), 173-182.

Cook-Sather, A., 2010. Students as Learners and Teachers: Taking Responsibility, Transforming Education, and Redefining Accountability. Curriculum Inquiry, 40(4), 555-575.

Cook-Sather, A. (2006), "'Change based on what students say': preparing teachers for a paradoxical model of leadership", International Journal of Leadership in Education: Theory and Practice, Vol. 9 No. 4, pp. 345-358.

Cook-Sather, A., 2002. Authorizing Students' Perspectives: Toward Trust, Dialogue, and Change in Education. Educational Researcher, 31(4), 3-14.

Cooperrider, D., Argyris.L., Whitney, D. and Stavros, J., 2003. Appreciative Inquiry Handbook: The First in a Series of Al Workbooks for Leaders of Change. Lake Shore Communications, Bedford Heights, $\mathrm{OH}$.

Czerniawski, G. \& Kidd, W., 2011. The Student Voice Handbook: Bridging the Academic/Practitioner Divide, Emerald, Bingley.

Dempster, N., 2009. What do we know about learning? In: J. MacBeath \& N. Dempster, eds. Connecting Leadership and Learning: principles for practice. Oxon: Routledge, 20-31.

Fielding, M., 2012. Beyond Student Voice: Patterns of Partnership and the Demands of Deep Democracy. Revista de Educación, 359, 45-65.

Fielding, M., 2010. The radical potential of student voice: Creating spaces for restless encounters. The International Journal of Emotional Education, 2(1), 61- 73.

Fielding, M., 2004. Transformative approaches to student voice: theoretical underpinnings, recalcitrant realities. British Educational Research Journal, 30(2), 295-311.

Fielding, M., 2001a. Beyond the Rhetoric of Student Voice: new departures or new constraints in the transformation of 21st century schooling?. Forum, 43(2), 100-110.

Fitzgerald, S.P., Murrell, K.L., \& Newman, H.L., 2001. Appreciative inquiry: The new frontier. In J. Waclawski \& A. H. Church (Eds.), Organizational development: Data driven methods for change. San Francisco, CA: Jossey-Bass, 203-221. 
Fullan, M., 2013. The New Pedagogy: Students and Teachers as Learning Partners. LEARNing Landscapes, 6(2), 23-29.

Garvin, D. A., Edmondson, A. C., \& Gino, F., 2008. Is yours a learning organization?. Harvard Business Review, 86(3), 109-119.

Giles, C. \& Hargreaves, A., 2006. The Sustainability of Innovative Schools as Learning Organisations and Professional Learning Communities During Standardized Reform. Educational Administration Quarterly, 42(1), 124-156.

Grant, S. \& Humphries, M., 2006. Critical evaluation of appreciative inquiry: Bridging an apparent paradox, Action Research, 4(4), 401-418.

Hargreaves, A. \& Fullan, M., 2012. Professional capital: Transforming teaching in every school. New York: Teachers College Press.

Hargreaves, A. and O'Connor, M. (2018), Collaborative Professionalism: When teaching together means learning for all, Corwin Press, Thousand Islands, CA.

Hargreaves, D.H., 2010. Creating a self-improving school system. Nottingham: National College for School Leadership.

Harris, A., 2008. Distributed School Leadership: Developing tomorrow's leaders, Oxon, UK: Routledge.

Harris, A. \& Muijs, D., 2005. Improving Schools Through Teacher Leadership, Maidenhead: Open University Press.

Hennessy, S., Mercer, N., \& Warwick, P., 2011. A Dialogic Inquiry Approach to Working with Teachers in Developing Classroom Dialogue. Teachers College Record, 113(9), 1906-1959.

Hill, S., 2019. Softening the hierarchy: the role of student agency in building learning organisations, Journal of Professional Capital and Community, Vol. 4 No. 2, pp. 147-162.

Jackson, D.B., 2003. Education Reform as If Student Agency Mattered: Academic Microcultures and Student Identity. The Phi Delta Kappan, 84(8), 579-585.

Kincheloe, J.L., \& Steinberg, S. R., 1998. Students as Researchers: Creating Classrooms that Matter, London: Routledge.

Kontoghiorghes, C., Awbrey, S.M., Feurig, P.L., 2005. Examining the Relationship Between Learning Organisation Characteristics and Change Adaptation, Innovation, and Organisational Performance. Human Resources Development Quarterly, 16(2), pp. 185-211. 
Lundy, L., 2007. 'Voice' is not enough: conceptualising Article 12 of the United Nations Convention on the Rights of the Child, British Educational Research Journal,33(6), 927-942.

MacBeath, J., Dempster, N., Frost, D., Johnson, G., \& Swaffield, S., 2018. Strengthening the connections between leadership and learning: challenged to policy, school and classroom practice, Oxon: Routledge.

MacBeath, J., 2009. What do we know about learning?. In MacBeath, J. \& Dempster, N. (Eds.). Connecting Leadership and Learning: Principles for Practice. Oxon: Routledge, pp. 4-19. MacBeath, J. \& Mortimore, P., 2001. School effectiveness and improvement: the story so far. Improving school effectiveness, 1-21.

Margolis, J. \& Doring, A., 2012. The Fundamental Dilemma of Teacher LeaderFacilitated Professional Development: Do as I (Kind of) Say, Not as I (Sort of) Do. Educational Administration Quarterly, 48(5), 859-882.

McIntyre, D., Pedder, D., \& Rudduck, J., 2005. Pupil voice: comfortable and uncomfortable learnings for teachers. Research Papers in Education, 20(2), 149-168.

Mitra, D.L., 2004. "The Significance of Students: Can Increasing "Student Voice" in Schools Lead to Gains in Youth Development?", Teachers College Record, 106(4), 651-688.

Moloi, K.C., 2010. How can schools build learning organisations in difficult education contexts?. South African Journal of Education, 30(4), 621-633.

Morgan, B., 2011. Consulting pupils about classroom teaching and learning: policy, practice and response in one school, Research Papers in Education, 26(4), 445-467.

Mullis, G., 2011. Student Voice: Changing Practice and Developing Partnerships. In G. Czerniawski \& W. Kidd. The student voice handbook: bridging the academic/practitioner divide (pp. 209-224). Bingley: Emerald.

Passmores Academy, 2019. Passmores Academy Research in Practice Journal, Volume 2, July 2019, Available from:

https://drive.google.com/open?id=1169snC6TtOjwpYbFKcjtdd5DnnirEewG [Accessed 27 February 2020].

Pearce, T.C., \& Wood, B.E., 2019. Education for transformation: an evaluative framework to guide student voice work in schools. Critical Studies in Education, 60(1), 113-130.

Pedder, P. \& Mclntyre, D., 2006. Pupil consultation: the importance of social capital. Educational Review, 58(2), 145-157. 
Roberts, A. \& Nash, J., 2009. Enabling students to participate in school improvement through a Students as Researchers programme. Improving Schools, 12 (2), 174-187.

Rudduck, J. \& Fielding, M., 2006. Student voice and the perils of popularity. Educational Review, 58(2), 219-231.

Rudduck, J., \& McIntyre, D., 2007. Improving learning through consulting pupils. London: Routledge.

Rushton, E.A.C., Charters, L., \& Reiss, M.J., 2019. The experiences of active participation in academic conferences for high school science students. Research in Science \& Technological Education, DOI: $\underline{10.1080 / 02635143.2019 .1657395}$

Ryan, F.J., Soven, M, Smither, J., Sullivan, W.M., \& Vanbuskirk, W.R., 1999. Appreciative Inquiry: Using Personal Narratives for Initiating School Reform, The Clearing House, 72(3), 164-167.

Senge, P., Cambron-McCabe, N., Lucas, T., Smith, B., Dutton, J., \& Kleiner, A., 2012. Schools That Learn. London: Nicholas Brealey Publishing.

Simons, H., 1996. The Paradox of Case Study. Cambridge Journal of Education, 26(2), 225240.

Stenhouse, L., 1983. The relevance of practice to theory. Theory Into Practice, 22(3), 211-215.

Swaffield, S., 2008. Critical friendship, dialogue and learning, in the context of Leadership for Learning. School Leadership \& Management: Formerly School Organisation, 28(4), 323-336.

Swaffield, S. \& Dempster, N., 2009. A Learning Dialogue (principle 3). In: J. MacBeath \& N. Dempster, eds. Connecting Leadership and Learning: principles for practice. Oxon: Routledge, 20-31.

Tashakkori, A. \& Teddlie, C., 2010. SAGE Handbook of Mixed Methods in Social and Behavioral Research: Second Edition. Thousand Oaks, CA: Sage Publications.

Thompson, P., 2009. Consulting secondary school pupils about their learning. Oxford Review of Education, 35(6), 671-687.

Thomson, P. \& Gunter, H., 2007. The Methodology of Students-as-Researchers: Valuing and using experience and expertise to develop methods. Discourse: Studies in the Cultural Politics of Education, 28(3), 327-342.

Timperley, H., Kaser, L., \& Halbert, J., 2014. A framework for transforming learning in schools: Innovation and the spiral of inquiry, Victoria: Centre for Strategic Education. Available from: 
http://www.educationalleaders.govt.nz/Pedagogy-and-assessment/Evidence-basedleadership/The-spiral-of-inquiry (accessed 12 January, 2020).

Warwick, P., Hennessy, S. \& Mercer, N., 2011. Promoting teacher and school development through co-enquiry: developing interactive whiteboard use in a "dialogic classroom." Teachers and Teaching: theory and practice, 17(3), 303324.

Waters, L., \& White, M., 2015. Case study of a school wellbeing initiative: Using appreciative inquiry to support positive change. International Journal of Wellbeing, 5(1), 19-32.

Yin, R.K., 2013. Case study research: Design and methods. London: Sage publications. 